\title{
LABOR RESOURCES IN AGRIBUSINESS IN CENTRAL-EASTERN EUROPE
}

\author{
Ewelina Szuba-Barańska ${ }^{1 凶}$, Aldona Mrówczyńska-Kamińska ${ }^{1}$, Walenty Poczta ${ }^{1}$ \\ ${ }^{1}$ Poznań University of Life Sciences, Poland
}

\begin{abstract}
The purpose of this study was to present the changes in agribusiness labor resources in CEE countries over the 1995-2014 period, and to examine whether the structure of these resources is observed to converge towards that of EU-15 countries. The number of agribusiness employees and the $\mathrm{I} / \mathrm{O}$ tables were retrieved from Eurostat and WIOD databases. Indicators of structural change were used to assess the convergence of agribusiness employment structure in countries covered by this study towards that of EU-15 countries. The largest number of agribusiness employees was observed in Poland and Romania. In 1995-2014, all countries covered by this study experienced a reduction in the number of people working in the agribusiness. Despite the growing importance of the $1^{\text {st }}$ sphere of agribusiness, the employment structure in agribusiness in most CEE countries continues to follow past patterns. In 2014, the average number of employees in the $1^{\text {st }}$ and $3^{\text {rd }}$ sector of agribusiness in these countries was 0.5 , compared to 2.2 in EU-15. However, a positive aspect is the slow approximation of agribusiness employment structures in CEE countries towards that of EU-15 countries. As shown by the results, in about 10 to 14 years, most countries covered by this study are likely to attain the employment structure observed in EU-15 in 2014. However, it may take up to 40 years for these structures to fully converge.
\end{abstract}

Keywords: approximation of structures, structural changes, agribusiness, employment

\section{INTRODUCTION}

Structural changes in labor resources are among the necessary criteria for economic development. The con- siderations in this paper refer to works by A.W. Lewis who identified two sectors of the economy (traditional agriculture and modern industry). The traditional sector mainly includes agriculture which addresses the needs of the rural community and provides food for the urban population but is characterized by inefficient use of labor resources and often exhibits high unemployment rates and extremely low levels of labor productivity. It is therefore necessary to move some of the excess labor resources from agriculture to the modern sector (including industry located in cities). This is how economic growth can be achieved through a growing marginal productivity of labor. The above translates into the development of manufacturing activities and further involvement of surplus labor released from agriculture (Bartkowiak, 2013). According to Tomczak (2001), the changes are necessary because a country cannot achieve significant levels of development if a considerable part of its potential and resources are allocated to food production. For many centuries, all around the world, food was delivered to the population directly through agriculture. Nowadays, in the $21^{\text {st }}$ century, food is created in a complex organism with interrelated components that form the whole food system, i.e. agribusiness.

As defined by Davis and Goldberg (1957), authors of this concept, agribusiness includes all economic activities related to the production and processing of agricultural raw materials, as well as the storage and distribution of agricultural commodities and products that originated from them. Agribusiness has evolved in the

$\bowtie$ Ewelina Szuba-Barańska, PhD, Department of Economics and Economy Policy in Agribusiness, Poznań University of Life Sci-
ences, Wojska Polskiego 28 St., 60-637 Poznań, Poland, e-mail: szuba@up.poznan.pl, https://orcid.org/0000-0002-4603-085X 
economies along with progressive changes in the social division of labor. In poorly developed economies, agriculture was the only sector responsible for food production. Later on, activities related to the manufacturing of production materials started to emerge as a separate sector, followed by the agri-food processing, trade and service sectors (Woś, 2004). Gradual processes of vertical integration between these activities were the basis for the formation of modern agribusiness (Woś, 1996) composed of: the industry responsible for the delivery of production materials and services for agriculture and the agro-food industry ( $1^{\text {st }}$ sphere $)$; agriculture $\left(2^{\text {nd }}\right.$ sphere $)$; and the agri-food industry ( $3^{\text {rd }}$ sphere). The internal structure of agribusiness evolves in line with the development processes taking place in the economies while agriculture loses its leadership. Therefore, an increasingly important role is played by agri-food processing and by industries in charge of delivering production materials and services for agriculture and agri-food sectors (and, at a later stage, for the trade sector) (Poczta and Mrówczyńska-Kamińska, 2004). This is manifested by changes in production performance, incomes and productive inputs involved, including labor. Along with the development of agribusiness, the number of agricultural employees should decrease. As a consequence, they should lose part of their share in employment in agribusiness to the other two spheres. As Wiatrak (1990) emphasizes, quantitative changes and related structural changes in labor resources are processes that depend on the country's level of economic development, agrarian structure, socioeconomic policy and degree of substitution of human labor by fixed assets. In countries where agricultural employment prevails over other areas of agribusiness (i.e. in nearly all CEE countries), the main difficulties in solving this issue are: low mobility of rural labor resources; lack of jobs in non-agricultural sectors; and (usually) an underdeveloped rural infrastructure which determines the ability to create new jobs in the countryside. Especially during significant restructuring of other sectors of national economy and massive reductions in employment, this makes agriculture a natural buffer that accumulates a significant part of the unemployed and creates an illusion of employment. Such a situation took place in many CEE countries. In this context, note the importance of non-agricultural activities in rural areas which could relieve surpluses in agricultural labor force. One might be tempted to say that agricultural development towards agribusiness would accelerate changes related primarily to reducing high employment in agriculture itself.

\section{PURPOSE, MATERIALS AND METHODS}

The purpose of this study was to present the changes in agribusiness labor resources in Central-Eastern European countries over the 1995-2014 period, and to examine whether the structure of these resources is observed to converge towards that of EU- $15^{1}$ countries. This study was also focused on determining the development gap between CEE and EU-15 countries in terms of the employment structure in agribusiness, and on estimating the time needed for the employment structures in CEE and EU-15 countries to become aligned.

The number of agribusiness employees and the I/O tables were retrieved from Eurostat and World Input-Output Database (WIOD) used for the purpose of this research. The number of agribusiness employees was determined based on the formula proposed by Woś (1979):

where:

$$
X_{A}=x_{r}+x_{p}+\sum_{i=1}^{n} x_{i} b_{i r}+\sum_{i=1}^{n} x_{i} b_{i p}
$$

$X_{A}-$ agribusiness labor resources

$x_{r}-$ agricultural labor resources

$x_{p}$ - labor resources of the agri-food industry

$x_{i}$ - labor resources in section (sub-sector) $i$ which is related to the agriculture and agri-food industry $(i+1,2, \ldots, n, n \neq r, p)$ and is indirectly involved in food production

$b_{i r}$ - coefficient which represents the flow of products and services from industry (sector) $i$ to the agriculture as a percentage of intermediate demand of industry (sector) $i$

$b_{i p}-$ coefficient which represents the flow of products and services from industry (sector) $i$ to the food industry as a percentage of intermediate demand of industry (sector) $i$.

According to the above formula, all agricultural and agri-food employees (and, to some extent, labor resources of sub-sectors indirectly involved in food production)

${ }^{1}$ In most EU-15 countries, a modern agribusiness structure is observed (see Mrówczyńska-Kamińska, 2015). Therefore, the employment structure in these countries was used as a European reference. 
were included in the agribusiness labor resources (pro rata to the volume of flows of material goods and services of sub-sector $i$ to the agriculture and agri-food industry). After determining the number of employees, the following was calculated: the employment structure in agribusiness of countries covered by this study; the share in employment in the national economy as a whole; and the ratio of employment in agriculture to employment in other areas of agribusiness. This enabled a partial assessment of the state of the art in agribusiness in CEE countries.

After determining the characteristics of agribusiness in CEE countries (Object A, lagged) and EU-15 (Object $B$, reference model), the process of the employment structures in agribusiness of the CEE and EU-15 states was approximated. Also estimated was the time needed for these structures to become aligned. According to the procedure proposed by Kukuła (2010), the analysis was carried out in seven steps:

1. The first step consisted in calculating the indicators of structural differences (Formula 1) between the countries considered in particular periods. The results of calculations fall within the interval $[0,1]$; if the values are closer to 0 , the structures are less diversified. Additionally, when the sequence of structural differentiation indicators is a growing (or quasi-growing) sequence, the structures move away from each other.

In the case of a constant (or quasi-constant) sequence, a constant distance between the structures is maintained, and in the case of a decreasing (or quasidecreasing) sequence, the examined structures approach each other. This means that the structure of object B can become identical to that of object A, as observed in the last period covered by this study.

$$
d_{t}=\frac{\sum_{i=1}^{k}\left|\alpha_{i t}-\beta_{i t}\right|}{2}(t=0, \ldots, n)(i=1, \ldots, k)
$$

This stage allowed to trace the changes in distance between the agribusiness employment structures in CEE and EU-15 countries.

2. The second step enabled determining the average pace of structural transformations $v$ in dynamic terms (Formula 2) based on agribusiness characteristics of both countries. The pace referred to above is the average value of chain-base indices showing the extent of transformation of a given structure from one period to another. An increase in the value of this indicator for the lagged object (B) accelerates the approximation process.

$$
\begin{aligned}
& v=\frac{\sum_{t=1}^{n} \sum_{i=1}^{k}\left|\alpha_{i t}-\alpha_{i(t-1)}\right|}{2 n} \\
& (t=0, \ldots, n)(i=1, \ldots, k)
\end{aligned}
$$

3. The next step was to determine the degree of monotonicity $\eta$ of structural changes (Formula 3 ). It allowed to assess whether the evolution of agribusiness structures keeps moving in the same general direction (this indicator falls within the interval $[0,1]$; if $\eta$ tends to zero, the structure is evolving in an increasingly chaotic manner, i.e. its components grow and decrease alternately). A higher degree of monotonicity means the structures are likely to become similar sooner.

$$
\eta_{m}=\frac{n_{n, 0}}{\sum_{t=1}^{n} v_{t, t-1}}(m=n)
$$

4. The fourth step consists in determining the disturbance factor (Formula 4) of the transformation of structure $\mathrm{z}$ resulting from the non-monotonicity of changes in the structure of the conforming country. This index is the inverse of the degree of monotonicity $\eta$ of structural changes taking place in this country.

Using this index, it is possible to adjust the time distance between both structures with fluctuations in the share of individual structural components that diverge from the development trend. If the structures are fully monotonic, the value of coefficient $z$ is 1 . If monotonicity decreases, the value of this index will increase.

$$
z_{m}=\frac{1}{\eta_{n B}}
$$

5. The fifth step of the procedure consisted in calculating the time distance $l$ (Formula 5) between the structures of both objects. It is the approximate time (number of periods) needed for the structure of the lagged object to attain the condition of the structure of the reference object as recorded in the $n$-th (last) observation period (assuming that the structure keeps moving in the same direction at a similar pace).

$$
l=\frac{z d_{n}}{v_{B}}
$$

6. In order to determine the time needed for the agribusiness employment structures in CEE and EU-15 countries to become similar, the values of the structural disruption factor $z^{\prime}$ (Formula 6), which takes into account the reduction in monotonicity of structures of both 
objects (A and B), were determined. A smaller degree of monotonicity of structures of both objects extends the time needed for the structure of object $\mathrm{B}$ to become identical to the structure of object A.

$$
z^{\prime}=\frac{2}{\eta_{n A}+\eta_{n B}}
$$

7. The last step of the procedure was to determine the time $l$ ' (Formula 7) needed for the structures of both objects to become identical. This is the approximate time (number of periods) needed for the structure of the lagged object to attain the condition of the structure of the reference object.

$$
l^{\prime}=\frac{z^{\prime} d_{n}}{v_{B}-v_{A}} v_{B}>v_{A}
$$

\section{RESULTS}

According to general development patterns, a decrease should be observed in the agricultural sector's share in the national production potential, production volume and incomes. It also means that the agribusiness structure should evolve towards one where the agricultural sector loses part of its share to the agri-food industry and to the entire supply and trade sector. As the economy develops, all sectors related to food production should also lose part of their share to other sectors. These relations may be used as a basis for assessing the state of the art of national agribusiness across the countries and its impact on the development level of the entire national economy.

The development processes in agribusiness were identified and studied based on changes in labor resources. As pointed out by Adam Smith (2007), labor is the only active and creative production input, while other inputs play an auxiliary role by establishing a business environment and creating the conditions for product development. This paper assessed the structure and importance of agribusiness in national economies of CEE countries based on employment figures. Also analyzed were the labor resources in agribusiness, their internal structure and share in the national economy as a whole. The results of these analyses are presented in Table 1. Of all the countries covered by this study, the highest levels of employment in agribusiness were recorded in Poland and Romania. These countries account for ca. $70 \%$ of all those working in agribusiness in the study area. At the same time, their local employment structures are extremely unfavorable due to a high share of agriculture. In 2014, there were only 0.7 people employed in the $1^{\text {st }}$ or $3^{\text {rd }}$ sphere of agribusiness per agricultural employee in Poland. The respective ratios for Romania and EU-15 countries are 0.2 and 2.2. The level recorded in Bulgaria (0.4) was also unfavorable. The worst structures of agribusiness employment were observed in Bulgaria and Romania where agriculture accounted for ca. $72 \%$ and nearly $85 \%$ of total agribusiness labor resources, respectively. Compared to other countries studied, Slovakia, Czech Republic and Estonia were found to have a relatively favorable employment structure in agribusiness (similar to that of EU-15 countries). In the Czech Republic and Estonia, about $30 \%$ of total agribusiness labor resources were engaged in agriculture, and ca. $42 \%$ in the provisioning sector. The remaining labor resources worked in the agri-food industry. In Slovakia, the employment structure in 2014 was even better because half of those employed in agribusiness were linked to the $1^{\text {st }}$ sphere, and farmers accounted for less than $27 \%$ of all employees. In these countries, the ratio of agricultural to other agribusiness employees was close to that observed in EU-15. This reflects the positive changes on the way towards a modern agribusiness. In other countries, approximately half of the agribusiness labor resources were employed in agriculture. A positive symptom of structural changes is the declining share of agriculture in employment structure, as currently witnessed in most countries covered by this study. Only Bulgaria and Romania did not experience any significant transformation in this area over the study period. It is true that during the period under consideration, these countries saw a decline in the number of agribusiness employees due to a reduction of employment in agriculture. However, there was no increase in employment in the $1^{\text {st }}$ sphere of agribusiness and no structural changes took place. In all countries covered by this analysis, the number of agribusiness employees decreased in 1995-2014, mainly due to loss of employment in the agriculture and agri-food sectors (except for Poland where agri-food employment increased by over 90,000). In Estonia, Lithuania and Latvia, in 2014, less than half of people worked in agribusiness compared to what was recorded 20 years earlier, while in Poland, Slovakia and Hungary, these figures were ca. $40 \%$ smaller. The reduction in agribusiness employment was also associated with a decrease in the proportion of food production employees in general employment 


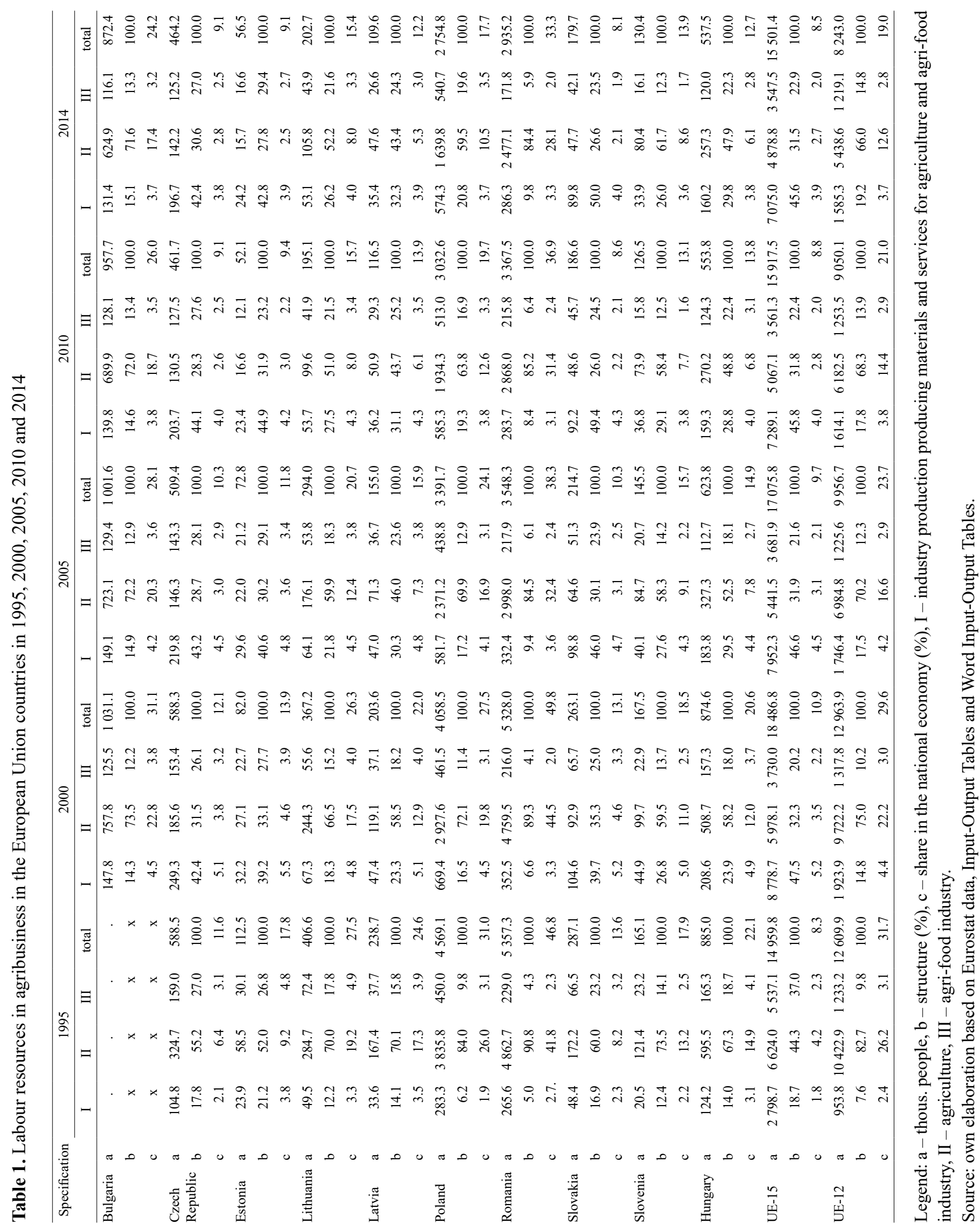


in the countries covered by this study. From 1995 to 2014, that ratio went down by over 9 percentage points in these countries, and yet remained more than twice as high as that recorded in the EU-15 (19\% vs. 8.5\%). Only in the Czech Republic, Estonia and Slovakia, less than $10 \%$ of domestic labor resources were involved in food production. In most countries covered by the analysis, this proportion varied in the range of $12 \%$ in Latvia to over $18 \%$ in Poland. In Bulgaria, nearly one quarter of national labor resources were associated with agribusiness (compared to more than one third in Romania). The reason for these high rates of employment in agribusiness is the excessive employment in agriculture. In the countries surveyed, it still has a dominant share in the structure of agribusiness labor resources while being much less important in the EU-15. Only the economic development of the countries surveyed will enable moving surplus labor from agriculture to other sectors, thus driving further structural changes and paving the way towards modern agribusiness.

The identification of structural changes taking place in agribusiness labor resources of CEE countries in 1995-2014 allowed to trace the convergence processes between labor resources structures in CEE and EU-15. These processes were found to occur in most countries covered by the analysis. Only in Bulgaria and Slovakia the agribusiness employment structure does not resemble that of EU-15 countries. This is indicated by the distance measures between employment structures in these countries and the EU-15 which followed an upward trend over the period $1995-2014$ (0.237 vs. 0.287 in Bulgaria and 0.157 vs. 0.243 in Slovakia) (Table 2). In Bulgaria, this situation is caused by the lack of major changes in the share of agriculture in agribusiness (a decrease by 2 percentage points in 14 years); this results in slight changes to the proportion of the other two sectors in the agribusiness employment structure. The lack of significant changes in the Bulgarian agribusiness employment structure is caused by a low level of economic development and the inability to transfer surplus employment from agriculture to other sectors. In Slovakia, however, a favorable structure of agribusiness employment was observed during most of the study period; that country also had a smaller proportion of agriculture than that recorded in the EU-15. Therefore, the distances between these structures are increasing. In other countries, the agribusiness employment structures converged towards what is observed in the EU-15, with the highest pace being recorded in Estonia (0.085) and Czech Republic (0.077). However, these changes were not fully monotonic, which is indicative of some disturbances affecting the evolution of structures concerned. As a consequence, taking into account the structural disruption factor of 1.252 and 1.398 , respectively, the time distance between agribusiness employment structures of these countries and that of the EU-15 was ca. 14 years in 2014. After determining the disturbance factor of structural changes, taking into account the monotonicity level of the structure for both lagged and model objects (z'), it was established that the agribusiness employment structure in these countries would be identical to that of the EU-15 around 2050. These changes will most probably involve a reduction in the share of the agri-food industry in $1^{\text {st }}$ sphere of agribusiness rather than a decline in the share of agriculture which is already quite low compared to other countries surveyed. Of the countries covered by this analysis, Latvia was found to have the shortest time distance (ca. 3.5 five-year periods) to the EU-15 agribusiness employment structure. This means that around 2032, these structures will be equal in these two objects. This pace of convergence was impacted by two facts. First, of all the countries considered, Latvia had the shortest distance to the EU-15 agribusiness employment structure in 2014 (0.071). Second, it evolved at more than half the speed of structural transformations taking place in the EU-15 (0.069). In addition, the relatively high degree of monotonicity of these changes (0.968) and a low structural disruption factor (1.033) are the reasons why in 2019 the Latvian agribusiness employment structure will reach the EU-15 level recorded in 2014. A less favorable situation was observed in Lithuania and Hungary. Although the distances between these structures and the EU-15 in 2014 indicated a fairly good situation compared to other countries surveyed (with $d_{t}$ values of 0.098 and 0.091 , respectively), the average pace of structural transformation was low (0.058 and 0.052). Also, Lithuania was additionally disturbed by the evolution of the agribusiness employment structure. Considering the disturbances in structural changes which stood at 1.290 in Lithuania and at 1,079 in Hungary, the approximate time needed for agribusiness employment structures of these countries to reach the EU-15 level recorded in 2014 is around 10 years. Due to sluggish changes and disturbances in the desired evolution of these structures (the disturbance of structural changes from z' is 1.657 and 1.472 , respectively), 
Szuba-Barańska, E., Mrówczyńska-Kamińska, A., Poczta, W. (2019). Labor resources in agribusiness in Central-Eastern Europe. J. Agribus. Rural Dev., 2(52), 179-187. http://dx.doi.org/10.17306/J.JARD.2019.01114

Table 2. Coefficients of diversity and convergence between agribusiness structures in the CEE and EU-15 countries

\begin{tabular}{|c|c|c|c|c|c|c|c|c|c|c|}
\hline Specification & Bulgaria & $\begin{array}{c}\text { Czech } \\
\text { Republic }\end{array}$ & Estonia & Latvia & Lithuania & Poland & Romania & Slovakia & Slovenia & Hungary \\
\hline $\begin{array}{l}\text { Gap in agribusiness employ- } \\
\text { ment structures between CEE } \\
\text { (B) and EU-15 (A) countries } \\
\text { in } 1995^{*}\end{array}$ & 0.237 & 0.109 & 0.103 & 0.257 & 0.259 & 0.397 & 0.428 & 0.157 & 0.293 & 0.230 \\
\hline $\begin{array}{l}\text { Gap in agribusiness employ- } \\
\text { ment structures between CEE } \\
\text { (B) and EU-15 (A) countries } \\
\text { in } 2014\end{array}$ & 0.287 & 0.167 & 0.171 & 0.098 & 0.071 & 0.166 & 0.415 & 0.243 & 0.191 & 0.091 \\
\hline $\begin{array}{l}\text { Average pace of structural } \\
\text { transformation of agribusiness } \\
\text { in CEE countries }(B) \text {, with } \\
\text { the average pace of structural } \\
\text { transformation of agribusiness } \\
\text { in EU-15 being } 0.0402\end{array}$ & $\mathrm{x}$ & 0.077 & 0.085 & 0.058 & 0.069 & 0.061 & 0.024 & $\mathrm{x}$ & 0.052 & 0.052 \\
\hline $\begin{array}{l}\text { Monotonicity of structural } \\
\text { changes in agribusiness em- } \\
\text { ployment in CEE countries } \\
\text { (B), with the monotonicity of } \\
\text { structural changes in agribusi- } \\
\text { ness in the EU-15 being } 0.4318\end{array}$ & $\mathrm{x}$ & 0.799 & 0.715 & 0.775 & 0.968 & 1.000 & 0.297 & $\mathrm{x}$ & 0.659 & 0.927 \\
\hline $\begin{array}{l}\text { Coefficient of disturbance to } \\
\text { structural changes }\end{array}$ & $\mathrm{x}$ & 1.252 & 1.398 & 1.290 & 1.033 & 1.000 & 3.369 & $\mathrm{x}$ & 1.518 & 1.079 \\
\hline $\begin{array}{l}\text { Time distance between the } \\
\text { agribusiness employment } \\
\text { structures in the CEE and EU- } \\
15 \text { countries in } 2014 \text { (number } \\
\text { of five-year periods) }\end{array}$ & $\mathrm{x}$ & 2.722 & 2.832 & 2.198 & 1.069 & 2.721 & 59.414 & $\mathrm{x}$ & 5.634 & 1.875 \\
\hline $\begin{array}{l}\text { Approximate year in which } \\
\text { the agribusiness employment } \\
\text { structure in CEE countries will } \\
\text { reach the condition recorded in } \\
\text { EU-15 in } 2014\end{array}$ & $\mathrm{x}$ & 2028 & 2028 & 2025 & 2019 & 2028 & 2311 & $\mathrm{x}$ & 2042 & 2023 \\
\hline $\begin{array}{l}\text { Coefficient of disturbance to } \\
\text { structural changes } z\end{array}$ & $\mathrm{x}$ & 1.625 & 1.744 & 1.657 & 1.428 & 1.397 & $\mathrm{x}$ & $\mathrm{x}$ & 1.834 & 1.472 \\
\hline $\begin{array}{l}\text { Time distance between the ag- } \\
\text { ribusiness employment struc- } \\
\text { tures in the CEE and EU-15 } \\
\text { countries (number of five-year } \\
\text { periods) }\end{array}$ & $\mathrm{x}$ & 7.416 & 6.738 & 9.396 & 3.553 & 11.144 & $\mathrm{x}$ & $\mathrm{x}$ & 31.091 & 11.041 \\
\hline $\begin{array}{l}\text { Approximate year in which } \\
\text { the agribusiness employment } \\
\text { structure in CEE countries will } \\
\text { be equal to that of EU-15 }\end{array}$ & $\mathrm{x}$ & 2051 & 2048 & 2061 & 2032 & 2070 & $\mathrm{x}$ & $\mathrm{x}$ & 2169 & 2069 \\
\hline
\end{tabular}

"In the case of Bulgaria, the convergence of agribusiness employment structures was analyzed based on data from 2000-2014. Source: own calculations based on Eurostat data, Input-Output Tables and Word Input-Output Tables. 
the Lithuanian agribusiness employment structure will reach the level of the EU-15 in about 2060, whereas the Hungarian will do so ten years later. Poland was the country who reduced the most the distance between the structures considered in 1995-2014. In the study period, the average pace of structural transformations in Polish agribusiness labor resources was $50 \%$ higher than in the EU-15 and amounted to 0.061 . The changes were fully monotonic (in each of the periods compared, the share of agriculture decreased and the spheres I and III). This suggests the evolving structures follow a constant trend. Therefore, despite being in a much worse condition at the beginning of the study period, Polish agribusiness will reach the EU-15 agribusiness employment structure recorded in 2014 around 2028 (similarly to the Czech Republic and Estonia who enjoyed a much better situation back in 1995). However, due to a low-level employment structure in Polish agribusiness (with a high share of agriculture) its convergence to the EU-15 structure could be completed only around 2070 . The above is also due to a relatively low degree of monotonicity of structural changes recorded in the EU-15 (also including the shift away from the $1^{\text {st }}$ sphere to the $3^{\text {rd }}$ sphere, which means changes in an opposite direction to what is experienced in Poland). The Romanian and Slovenian agribusiness employment structures converge towards that of the EU-15 at a very slow pace. In Romania, the structure moved slightly closer to that of the EU-15. However, the rate of structural transformation is slower than what is recorded in the EU-15 (0.021 vs. 0.040), and the monotonicity of structural changes $(0.726)$ suggests the transformation is affected by disturbances. Therefore, even though the formal results suggest that the Romanian agribusiness employment structure will ultimately reach the 2014 status of the EU-15 in 2144, it can be stated that no convergence process is observed. In Slovenia, however, the share of agriculture in the agribusiness employment structure follows a very slow downward trend (in the last year under review, an increase was even noted) which results in these structures moving slowly towards those of the EU-15. In fact, the distance between the Slovenian and EU-15 structures in 2014 was only 0.191 , but the speed of structural transformation is quite low (0.052) and the structure evolves on a nonmonotonic basis (the monotonicity degree of structural changes was 0.659). As a result, it is only around 2042 that this structure will reach the 2014 status of the EU-15; based on these findings, the equalization of both structures may take place only around 2169. The results of analyses should be treated more as an indication of the development gap than a forecast. In the long term, qualitative factors of development may play an important role.

\section{SUMMARY}

Changes that take place in the agribusiness employment structure of CEE countries are consistent with the development patterns followed by that sub-sector. Only in Bulgaria and Romania, as before, there are no clear signals of the development of a modern agribusiness; a significant proportion of employees across the economy are involved in the production of foods. As a result of development processes, all countries surveyed witness a reduction in the number of agricultural employees and a declining importance of agriculture in relation to other areas of agribusiness and to the entire national economy. However, despite these favorable changes, the employment structure in agribusiness in most CEE countries suggests this sector is still far from being a modern part of the economy. The most favorable situation in this respect was recorded in Slovakia where the agribusiness employment structure was similar to that in the EU-15 during most of the study period. In 19952014, the most favorable changes moving the agribusiness structures closer to those of the EU-15 were experienced in the Czech Republic and Estonia. As at 2014, these countries had the smallest percentage of workforce involved in food production and the lowest share of agriculture in the internal structure of agribusiness employment. Also, together with Latvia, they have the smallest gap separating their agribusiness employment structures from what is recorded in the EU-15. The equalization of these structures with the EU-15 will take place around 2032 in Latvia and around 2050 in the Czech Republic and Estonia. Countries with a less favorable employment structure in agribusiness (with a predominant role of agriculture) are Poland, Lithuania and Hungary. In the two latter, a fairly slow pace of structural transformation was observed, resulting in a long, 50-year period needed to align their agribusiness employment structure with those of EU-15 countries. In Poland, however, the employment structure in agribusiness was consistently improving throughout the period under consideration. This being said, note that as a dominant part of labor resources involved in food 
production works in agriculture, the agribusiness structure will fully converge with that of the EU-15 only around 2070 .

In all countries covered by this study, it is necessary to create conditions for the development of modern agribusiness. This may include the creation of companies from the agricultural environment (e.g. small agro-food processing, consulting or financial intermediation establishments, rental of machinery and equipment) which cooperate directly with agriculture. It will enable an outflow of the agricultural population from agriculture to newly created jobs and, as a consequence, will contribute to creating sound relations with the entire national economy while also driving the emergence of a modern agribusiness. Also, it will help accelerating the sluggish evolution of the agribusiness employment structure in CEE countries towards what is in place in the EU-15, characterized by a much more modern agribusiness.

\section{SOURCE OF FINANCING}

The study was supported by National Centre of Science grant. No project: 2014/13/N/HS4/03617 titled "The development of agribusiness in Central-Eastern European countries in the context of the European Union membership".

\section{REFERENCE}

Bilanse przepływów międzygałęziowych. Retrieved on June $5^{\text {th }} 2017$ from: www.ec.europa.eu/eurostat

Bartkowiak, R. (2013). Ekonomia rozwoju. [Development of economy]. Warszawa: PWE [in Polish].

Davis, J., Goldberg, R. (1957). A Concept of Agribusiness. Boston: Harvard University.

EC (n.d.). National accounts employment data by industry. Retrieved June $5^{\text {th }} 2017$ from: www.ec.europa.eu/eurostat
Kukuła, K. (2010). Dynamika struktur [Dynamics of structures]. In: K. Kukuła, Statystyczne studium struktury agrarnej w Polsce [Statistical study of agrarian structure in Poland]. Warszawa: Wyd. Nauk. PWN [in Polish].

Mrówczyńska-Kamińska, A. (2015). Gospodarka żywnościowa w krajach Unii Europejskiej: kierunki rozwoju, przepływy i współzależności. [Food economy in European Union countries: directions of development, flows and interdependencies]. Poznań: Wyd. UPP [in Polish].

Poczta, W., Mrówczyńska-Kamińska, A. (2004). Agrobiznes w Polsce jako subsystem gospodarki narodowej [Agribusiness in Poland as a subsystem of the national economy]. Poznań: Wyd. AR im. Augusta Cieszkowskiego w Poznaniu [in Polish].

Smith, A. (2007). Badania nad naturą i przyczynami bogactwa narodów [Research on the nature and causes of the wealth of nations]. T. 1. Warszawa: Wyd. Nauk. PWN [in Polish].

Tomczak, F. (2001). Przyszłość wsi polskiej w kontekście doświadczeń światowych [The future of the Polish village in the context of world experience]. In: L. Kolarska-Bobińska, A. Rosner, J. Wilkin, Przyszłość wsi polskiej - wizje, strategie, koncepcje [The future of the Polish village views, strategies, concepts] (pp. 155-173). Warszawa: ISP [in Polish].

Wiatrak, A. (1990). Zasoby siły roboczej w rolniczych gospodarstwach rodzinnych [Workforce resources in agricultural family farms]. Warszawa: Wyd. Nauk. PWN [in Polish].

World Input-Output Tables (n.d.). Retrieved March $5^{\text {th }} 2018$ from: http://www.wiod.org/home

Woś, A. (1979). Związki rolnictwa z gospodarką narodową [Relations between agriculture and the national economy]. Warszawa: PWRiL [in Polish].

Woś, A. (1996). Agrobiznes. Makroekonomika [Agribusiness. Macroeconomics] (vol. 1). Warszawa: Key Text [in Polish].

Woś, A. (2004). W poszukiwaniu modelu rozwoju polskiego rolnictwa [In search of a model for the development of Polish agriculture]. Warszawa: IERGŻ [in Polish]. 